\title{
GROWTH AND PRODUCTIVITY OF SHORT DURATION AMAN RICE GENOTYPE
}

\author{
M. S. Hasan, A. R. Khan*, M. Islam and M. M. Haque \\ Department of Agronomy, Bangabandhu Sheikh Mujibur Rahman Agricultural University, Gazipur 1706 \\ *Corresponding author, E-mail: arifkhanbsmrau@gmail.com
}

(Received: 21 April 2017, Accepted: 21 December 2017)

Key words: variety, advanced line, growth, yield, harvest index

\begin{abstract}
A field experiment was conducted at the research field of Agronomy Department of Bangabandhu Sheikh Mujibur Rahman Agricultural University during Aman season of 2014. Twenty four day old seedlings were transplanted in the main filed in a randomized complete block design with three replications. The advanced rice line $\mathrm{BU}-$ 9958-40-5-1 was compared with BRRI dhan56, BRRI dhan57, Binadhan-7 and BU dhan1. Results showed that rice var. BRRI dhan57 matured earlier [81 days after transplanting (DAT)] while the advanced line took the maximum days (90 DAT) to mature in the field. Although the tallest plant $(113.80 \mathrm{~cm})$ was observed in BRRI dhan56 but tiller number (12.22), leaf area index (4.67) and dry matter production (398.69 $\left.\mathrm{g} \mathrm{m}^{-2}\right)$ were the highest in advanced line BU-9958-40-5-1. The advanced line produced the highest grain yield $\left(5.98 \mathrm{t} \mathrm{ha}^{-1}\right)$ coupled with the highest biological yield $\left(11.55 \mathrm{t} \mathrm{ha}^{-1}\right)$ but failed to show the highest harvest index. Thus it seemed that this line was not much efficient in converting total dry matter into grain which is the ultimate target of crop production. Therefore, this result can help physiologists and breeders to determine physiological and morphological features of the advanced line BU-9958-405-1 that contribute the most to increasing dry matter partition into grain.
\end{abstract}

\section{Introduction}

In Bangladesh, rice is main food for about 160 million people where it covers about $80 \%$ of total cropped area (BBS, 2013). In aman season, thousands of land races and cultivars are used all over the country. These races are mostly long duration which delay establishment of winter crops and reduce system productivity. Therefore, introduction of short duration aman rice is imperative to crop intensification as well as to enhance system productivity. Further, short duration aman rice can create opportunity to evolve even four crops in sequence in a year (Haque and Rashid, 2016). Besides, crop intensification and system productivity of yield improvement of short duration aman rice cannot be ignored. Yield improvement of aman rice can be done by breeding method with high yielding genotypes and short duration rice characteristics.

Very recently, Department of Genetics and Plant Breeding, Bangabandhu Sheikh Mujibur Rahman Agricultural University (BSMARU) developed an advanced line (BU-9958-40-5-1) which is short duration, high zinc and iron content, mild aroma and expected to give higher yield than the released short duration varieties. Therefore, this line needs further test to compare yield performance with other released short duration rice varieties growing in aman season. Keeping these views in mind, the present study was aimed to evaluate yield potential of 
Hasan et al.

advanced line (BU-9958-40-5-1) and compare to growth and productivity of different short duration aman rice.

\section{Materials and Methods}

The experiment was conducted at the Agronomy research field of Bangabandhu Sheikh Mujibur Rahman Agricultural University, Gazipur during aman season of 2014. It is located in Madhupur Tract under Agro Ecological Zone- 28 at geographic coordinate 24 05' North latitude and 90 16' East longitude with an elevation of $8.4 \mathrm{~m}$ above the mean sea level. The soil of the experimental site is silty clay in surface and silty clay loam in sub-surface region. The site is situated in the sub-tropical region characterized by heavy rainfall during monsoon at the months from May to September and scanty rainfall in the rest of the months of the year. The experimental variables consist of four short duration aman rice varieties viz. BRRI dhan56, BRRI dhan57, Binadhan-7, BUdhan1 and one advanced line BU-9958-40-5-1. The experiment was laid out in randomized complete block design with three replications. The unit plot size was $5 \mathrm{~m} \times 4 \mathrm{~m}$ and spacing was $20 \mathrm{~cm} \times 20 \mathrm{~cm}$. Rice seedlings of 24 days old were transplanted on August 17, 2014 with two seedlings per hill on well puddle soil. Gap filling was done within two weeks after transplanting. Except nitrogen, the crop was fertilized with a blanket dose of fertilizers 60-50-40-20-4 @ N-P-K-S-Zn kg ha-1 respectively at the time of final land preparation. Nitrogen was applied in the form of urea in two installments as top dressing. First top dressing was done at 15 days after transplanting (DAT) and second at 30 DAT. Two hand weedings were done at 15 and 30 DAT to prevent weed infestation. Furadan $5 \mathrm{G} @ 10$ $\mathrm{kg} \mathrm{ha}{ }^{-1}$ was applied to control the infestation of stem borer at active filleting stage. After transplanting, sufficient amount of water was maintained in each plot by supplementary irrigation throughout the growing period. Standing water was maintained in the field at 2 to 4 $\mathrm{cm}$ until hard dough stage was reached.

Data on different growth parameters, yield components and yield were recorded. Plant samples were collected at 10 days interval starting from 15 DAT till maturity. At each sampling, three hills were uprooted sequentially from a single row. To avoid border effect, plants were sampled from second and third rows at each sampling time. The above ground plant parts were segmented into different components as leaf, stem, leaf sheath and panicle. Leaf areas of sampling were measured by an automatic leaf area meter (AAM-8, Hayashi Dehnko, Japan) immediately after sampling. The partitioned plant parts were then dried in an oven at $70^{\circ} \mathrm{C}$ for 72 hours and weighed. Grains and straw obtained from each unit plot were sun dried and weighed. The grain yield and straw yield was converted tot ha- ${ }^{-1}$. Data on different parameters were statistically analyzed using procedure described by Gomez and Gomez (1984) and means were compared using least significant difference by LSD test.

\section{Results and Discussion}

\section{Phenological events}

Phenological events differed significantly among the aman rice genotypes (Table 1). Days to $50 \%$ flowering (45) and days to $100 \%$ flowering (49) were the least in BRRI dhan57 and it matured at 81 DAT which was statistically similar with BRRI dhan56. However, days to $50 \%$ flowering (57) and days to 100\% flowering (61) were the longest in BU-9958-40-5-1 and it matured at 90 DAT. Other genotypes matured within intermediate times. Such variation in phenological events observed among the genotypes might be due to environmental factors as 
well as their genetic make-up. Sometimes, quick vegetative growth of plants resulted in early switch over to reproductive phase (Reddy, 2004). These findings are conformity with findings of Udayakumar (2005).

\section{Soil Plant Analysis Development (SPAD) values}

The SPAD measures the content of leaf chlorophyll pigment. The SPAD values differed significantly among the genotypes (Table 1). Numerically, the lowest SPAD value (26.62) was recorded from BRRI dhan57. On the other hand, the advanced line BU-9958-40-5-1 gave the highest SPAD value (36.74). Higher photosynthesis rate in different variety is supported by leaf chlorophyll content in leaf blades (Miah et al., 1997). In present study, higher SPAD value recorded in the advanced line BU-9958-40-5-1 indicated that this genotype possessed higher photosynthetic capacity and dry matter production than other genotypes.

Table 1. Phenological events and SPAD value of aman rice genotypes

\begin{tabular}{lcccc}
\hline Genotypes & $\begin{array}{c}50 \% \text { flowering } \\
\text { (DAT) }\end{array}$ & $\begin{array}{c}100 \% \text { flowering } \\
\text { (DAT) }\end{array}$ & $\begin{array}{c}\text { Maturity } \\
\text { (DAT) }\end{array}$ & SPAD value \\
\hline BRRI dhan56 & 49 & 53 & 82 & 29.97 \\
BRRI dhan57 & 45 & 49 & 81 & 26.62 \\
BINAdhan-7 & 53 & 58 & 85 & 32.70 \\
BU dhan1 & 57 & 61 & 87 & 35.50 \\
BU-9958-40-5-1 & 57 & 61 & 90 & 36.74 \\
\hline CV (\%) & 1.49 & 1.48 & 0.77 & 5.47 \\
LSD $(0.05)$ & 1.46 & 1.58 & 1.24 & 3.33 \\
\hline
\end{tabular}

\section{Plant height}

Irrespective of genotypes plant height of Aman rice increased progressively with the increased growth duration from transplanting to maturity (Fig. 1). The plant height also significantly affected among the rice genotypes. Results showed that the genotype BRRI dhan 56 produced the tallest plant at all sampling dates and it was the highest $(113.80 \mathrm{~cm})$ at harvest. The rice genotype Binadhan-7 produced the shortest plant $(102.56 \mathrm{~cm})$ which was statistically similar $(104.45 \mathrm{~cm})$ to BRRI dhan57. BU-9958-40-5-1 $(107.03 \mathrm{~cm})$ and BU dhan1 $(105.98 \mathrm{~cm})$ produced the second highest plant height. This variation in plant height was probably due to the genetically make-up of the genotypes. These results were consistent with those of Naha (2007) and Kamal (2006).

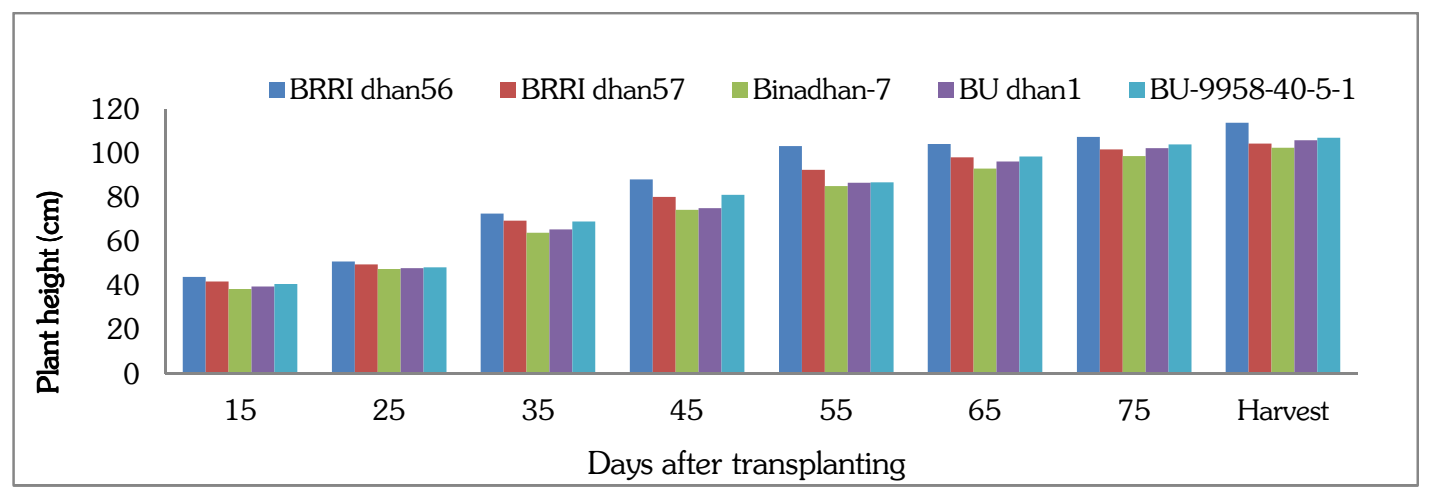

Fig. 1. Plant height of different aman rice genotypes over the growing period 
Hasan et al.

\section{Number of tillers hill ${ }^{-1}$}

Number of tillers hill ${ }^{-1}$ was significantly influenced by the rice genotypes (Fig. 2). Number of tillers hill ${ }^{-1}$ of aman rice increased over time. The highest number of tillers hill ${ }^{-1}$ (12.22) was counted in BU-9958-40-5-1 and the lowest tillers hill-1 (8.33) was observed in BRRI dhan57 at harvest. BRRI dhan56 had the second highest number (10.67) of tillers hill ${ }^{-1}$. Binadhan-7 and BU dhan1 had the third highest number of tillers hill ${ }^{-1}$ which was 10.44 and 10.44 , respectively. Variable effect of variety on number of tillers hill- ${ }^{-1}$ was also reported by Guowei et al. (1998) who noticed that total tillers $\mathrm{m}^{-2}$ differed significantly among the varieties in aman season. The variation in number of tillers hill ${ }^{-1}$ might be due to varietal attributes and genetical characters.

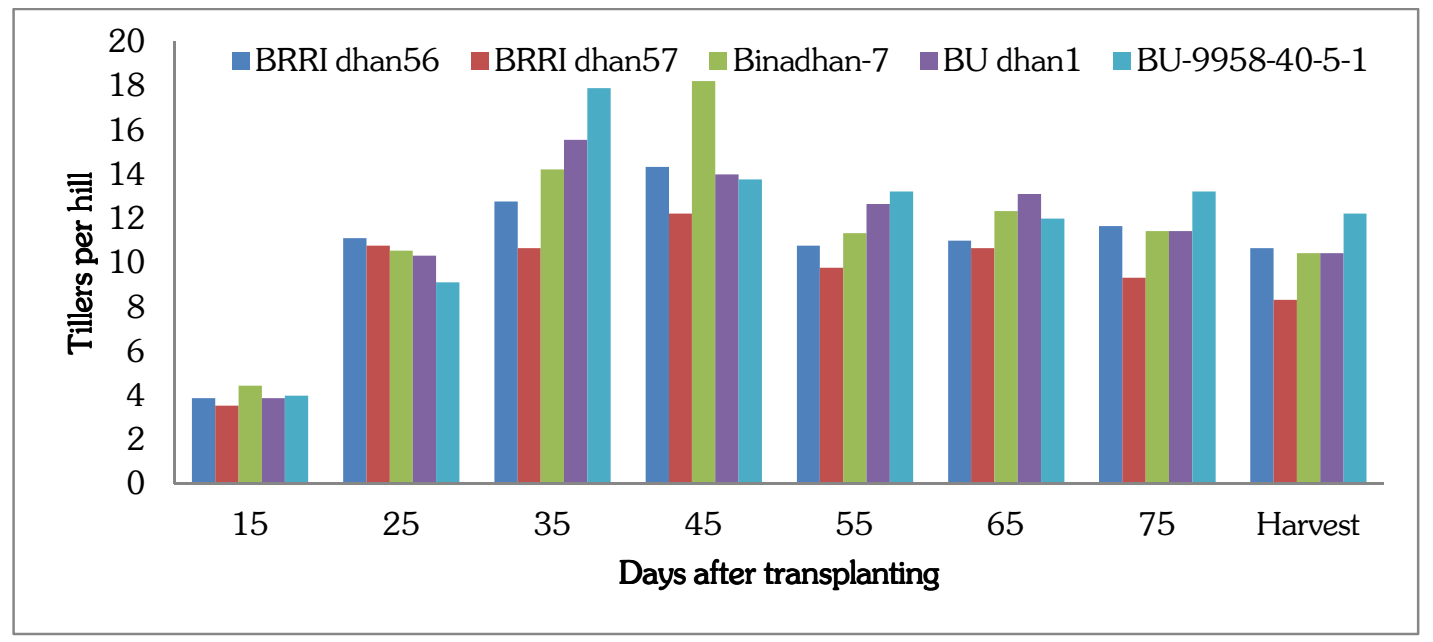

Fig. 2. Number of tillers hill-1 ${ }^{-1}$ of aman rice genotypes over the growing period

\section{Leaf area index}

Leaf area index (LAI) was significantly influenced by different rice genotypes. The LAI increased progressively up to 55 DAT but later the curve leaned downwards (Fig. 3). Such decline in LAI might be due to leaf senescence. The highest leaf area index (5.42) was found at 55 DAT in BU-9958-40-5-1 and it decreased to 4.67 at harvest. The lowest LAI (4.21) was recorded in BRRI dhan57 which was statistically similar with BRRI dhan56 at harvesting stage. The second highest LAI (4.57) was obtained in BU dhan1 and then LAI (4.46) of Binadhan-7. This result showed that genotypic variation in LAI was confirmed the finding of Reddy et al. (1995) who reported that rice genotypes differed markedly in LAI and net assimilation rate.

\section{Dry matter partitioning}

Variation in dry matter production in leaf, leaf sheath, stem and panicle was statistically significant over the rice genotypes (Fig. 3). The highest leaf blade, leaf sheath and stem dry matter was obtained from BU-9958-40-5-1 at all the growth stages. The highest panicle (398.69 $\mathrm{g} \mathrm{m}^{-2}$ ) dry weight was also obtained from BU-9958-40-5-1 at all stages. In general, pattern of dry matter partitioning into leaf, stem, leaf sheath and panicle of rice was almost similar across the rice genotypes. Dry matter partitioning into leaf, stem and leaf sheath increased up to 55 days after transplanting while panicle dry weight continued to increase till maturity. Dry matter partitioning into vegetative organs decreased after 55 days after 
Growth and Productivity of Short Duration Genotypic

transplanting which indicated remobilization of assimilates from vegetative parts towards developing grain. Several authors (Barvestani and Pirdashti 2001; Ntanos and Koutroubus, 2002) showed that two physiological processes are involved in grain growth; utilization of photosynthates through current photosynthesis and remobilization and translocation of assimilates accumulated before anthesis. In present study, it seemed that stem had higher amount of dry matter remobilization than other vegetative organs of rice as reduction of stem reserve was more pronounced. This result was in consistent with the findings of Yang et al. (2003) and Kumar et al. (2006) and they reported that different rate of remobilization among the rice genotypes were reported to their agronomic and physiological characteristics.

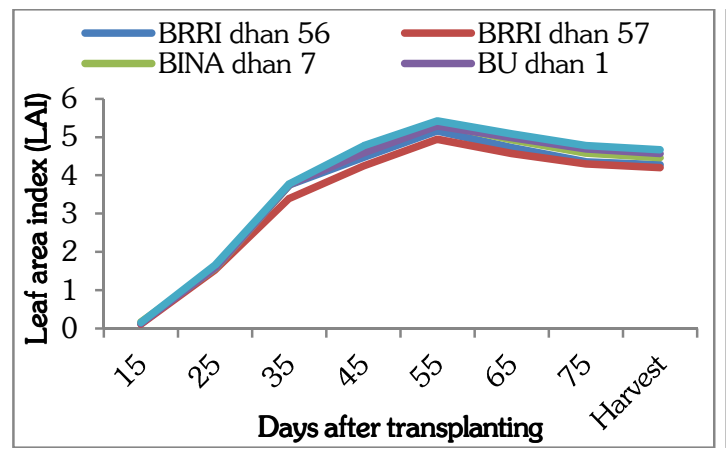

(a)

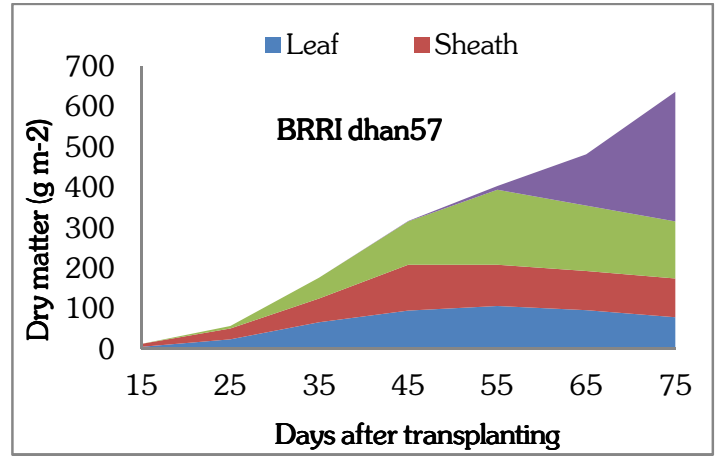

(c)

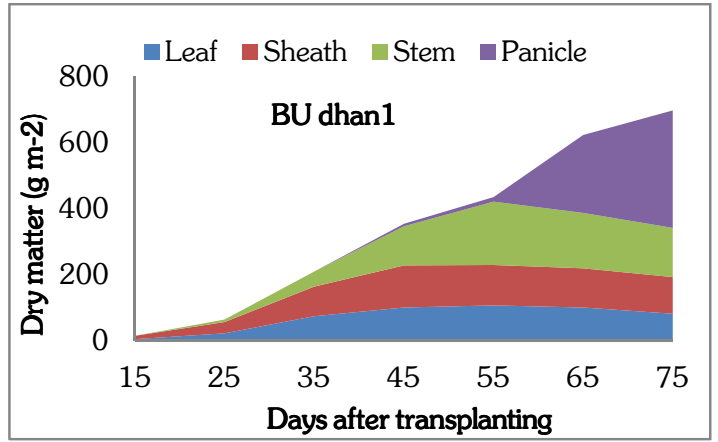

(e)

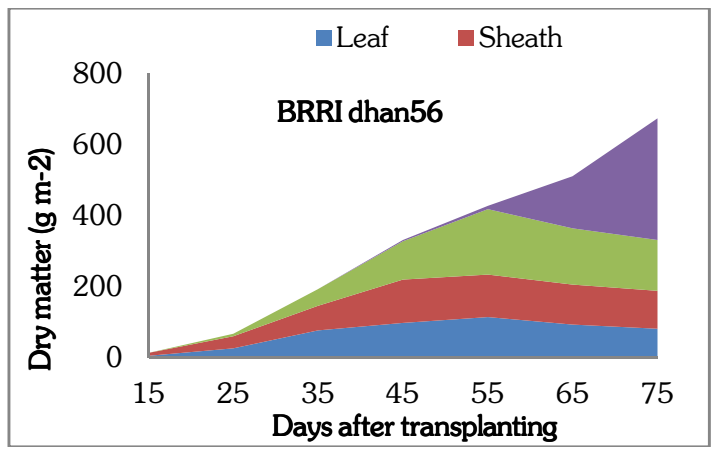

(b)

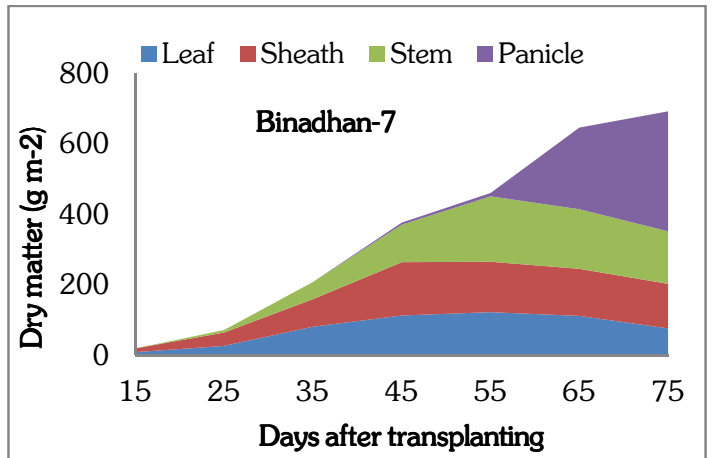

(d)

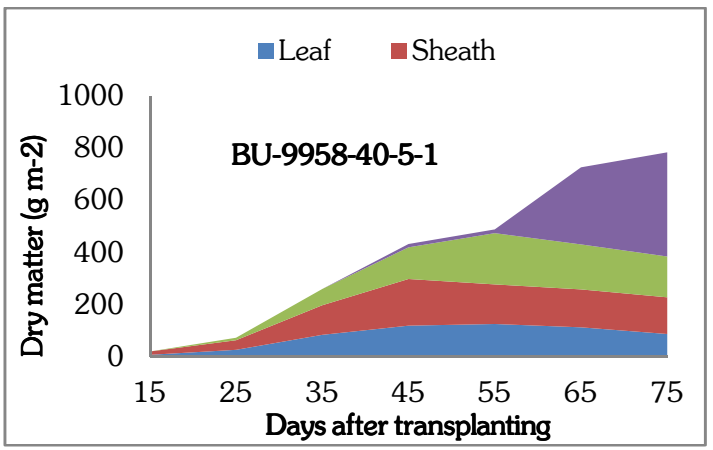

(f)

Fig. 3. Pattern of leaf area index (a) and dry matter partitioning to different parts of rice genotypes (b, c, d, e, and f) over the growing period. 
Hasan et al.

\section{Number of panicles $\mathrm{m}^{-2}$}

Number of panicles $\mathrm{m}^{-2}$ varied significantly among the rice genotypes. Results showed that the maximum panicles $\mathrm{m}^{-2}$ (310.00) was produced by BU-9958-40-5-1 which was statistically similar with Binadhan-7 (273.25), BU dhan1 (268.25), and BRRI dhan56 (265.00). The rice genotype BRRI dhan57 produced the lowest number of panicles $\mathrm{m}^{-2}(215.00)$ and it was statistically similar with BRRI dhan56, Binadhan-7 and BU dhan1 (Table 3). The variation in number of panicles $\mathrm{m}^{-2}$ might be due to genetical characteristics of rice genotypes. Miller et al. (1991) observed that panicles $\mathrm{m}^{-2}$ were the most important component of yield and accounted for $89 \%$ of the varieties in yield. The genotypic variation in panicles $\mathrm{m}^{-2}$ was also similar to that which noted by Shamsuddin et al. (1988) under rainfed condition in aman season.

\section{Panicle length}

There was significant variation in panicle length of rice genotypes. The longest $(28.40 \mathrm{~cm})$ panicle was obtained from BU-9958-40-5-1 and the lowest $(22.94 \mathrm{~cm}$ ) in BRRI dhan57 (Table 2). Alam et al. (2002) also found varietal differences in panicle length of rice where the variety with the longest panicle contributed more spikelets per panicle. Thus, like other yield components, panicle length is also considered as important parameter of yield enhancement of rice.

Table 2. Grain yield and yield components of aman rice genotypes

\begin{tabular}{lccccc}
\hline Genotypes & $\begin{array}{c}\text { Number of } \\
\text { Panicles }^{-2}\end{array}$ & $\begin{array}{c}\text { Panicle } \\
\text { length }(\mathrm{cm})\end{array}$ & $\begin{array}{c}\text { Grains } \\
\text { panicle }^{-1}\end{array}$ & $\begin{array}{c}\text { 1000-grain } \\
\text { weight }(\mathrm{g})\end{array}$ & $\begin{array}{c}\text { Grain yield } \\
\left(\mathrm{t} \mathrm{ha}^{-1}\right)\end{array}$ \\
\hline BRRI dhan56 & 265.00 & 26.36 & 155.68 & 22.56 & 4.12 \\
BRRI dhan57 & 215.00 & 22.94 & 149.86 & 16.63 & 3.43 \\
Binadhan-7 & 273.25 & 23.74 & 134.70 & 22.95 & 4.60 \\
BU dhan1 & 268.25 & 24.53 & 116.58 & 26.60 & 5.14 \\
BU-9958-40-5-1 & 310.00 & 28.40 & 127.17 & 24.14 & 5.98 \\
\hline CV (\%) & 15.48 & 1.50 & 9.16 & 2.19 & 6.91 \\
LSD $(0.05)$ & 3.10 & 0.71 & 17.86 & 0.93 & 0.61 \\
\hline
\end{tabular}

\section{Number of grains panicle ${ }^{-1}$}

Aman rice genotypes differed significantly in respect of number of spikelets panicle $e^{-1}$. Table 2 showed that BRRI dhan56 produced the maximum number of grains panicle $e^{-1}$ (164.83) which was statistically similar with BRRI dhan57 and BU-9958-40-5-1. The lowest number of grains panicle $^{-1}$ (117.90) was observed with BU dhan1 which was statistically similar (127.50) to Binadhan-7. Singh and Gangwar (1989) also reported variable number of grains panicle $e^{-1}$ among different rice genotypes. Shortage of assimilates may occur either due to limitation of source or deficiencies of any nutrient. Varietal differences regarding the number of grains panicle $e^{-1}$ might be due to their genetic constitution that differentiated in photosynthetic assimilate accumulation especially after heading. Therefore, there is possibility to increase number of grains panicle ${ }^{-1}$ by adopting proper agronomic manipulation.

\section{0-grain weight or test weight}

Genotypes showed significant variation in 1000- grain weight. The highest test weight $(26.60$ g) was obtained from BU dhan1 and the lowest one (16.63 g) from BRRI dhan57 (Table 2). Rice genotype BU-9958-40-5-1 produced the second highest (24.14 g) test weight. Although 
1000- grain weight is genetically controlled but it might be changed to some extent due to changes in environmental condition. In the present study, variation in test weight was observed although non-significant variation in test weight of different modern rice varieties was observed by Islam et al. (1999).

\section{Grain yield}

Grain yield varied significantly among the rice genotypes which ranged from 3.43 to $5.98 \mathrm{t}$ $\mathrm{ha}^{-1}$ (Table 2). Among the genotypes, BU-9958-40-5-1 produced the highest grain yield. which was associated with its better yield components especially number of panicles hill-1. Maximum contribution of number of panicles in improving grain yield was also confirmed by having strong correlation of this component with grain yield (Fig. 4). On the other hand, BRRI dhan57 produced the lowest grain yield. Such differences in production potential of rice were recorded by Naha (2007), Mumin (2002) and Biswas et al. (1998) who observed variable grain yield among rice varieties.

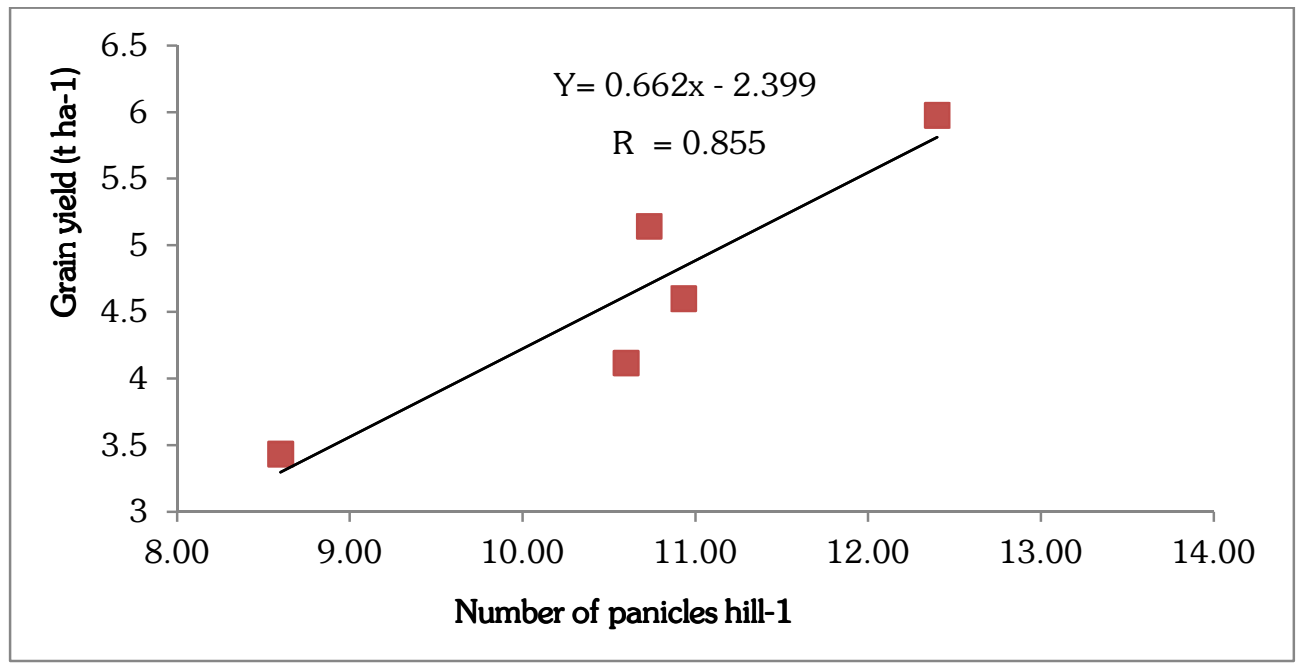

Fig. 4. Relationship between number of panicles hill ${ }^{-1}$ and grain yield of aman rice genotypes

\section{Straw yield}

Data regarding straw yield showed significant variation among the rice genotypes (Table 3). It was evident that the maximum straw yield $\left(5.79 \mathrm{t} \mathrm{ha}^{-1}\right)$ was produced by $\mathrm{BU}$ dhan 1 which was statistically similar to BU-9958-40-5-1 and Binadhan-7. BRRI dhan57 had given the second highest straw yield (4.17 t ha-1) which was statistically identical (3.81) to BRRI dhan56. These results were consistent with those of Khisha (2002) and Chowdhury et al.,1995 who also observed significant variation in straw yield among the varieties.

\section{Biological yield}

The highest biological yield (11.55 $\mathrm{t} \mathrm{ha}^{-1}$ ) was obtained from BU-9958-40-5-1 which was statistically similar (10.74 $\left.\mathrm{t} \mathrm{ha}^{-1}\right)$ with BU dhan1 and Binadhan-7. The genotypes which had higher straw and grain yield that in turn increased the biological yield Islam et al.,2014. The lowest biological yield $\left(7.61 \mathrm{t} \mathrm{ha}^{-1}\right)$ was obtained from BRRI dhan57 which was statistically similar (7.93 t ha-1) with BRRI dhan56. Lamberts et al. (2007) also observed similar result and concluded that different varieties of transplant Aman rice show variation in biological yield. 
Hasan et al.

\section{Harvest index}

Rice genotypes exerted significant effect on harvest index (Table 3). The maximum harvest index (52.31\%) was observed in BRRI dhan56 which was statistically similar with Binadhan-7, BU dhan1 and BU-9958-40-5-1. The lowest (45.63\%) was recorded in BRRI dhan57 which was statistically identical to Binadhan-7, BU dhan1 and BU-9958-40-5-1. It is the genetically attributes that showed variation in harvest index of different rice genotypes. Tyeb (2012) observed the similar results and concluded that harvest index depends on inherent genetical attributes and the prevailing environmental condition of the growing season.

Table 3. Straw yield, biological yield and harvest index of aman rice genotypes

\begin{tabular}{lccc}
\hline Genotypes & $\begin{array}{c}\text { Straw yield } \\
\left(\mathrm{t} \mathrm{ha}^{-1}\right)\end{array}$ & $\begin{array}{c}\text { Biological yield } \\
\left(\mathrm{t} \mathrm{ha}^{-1}\right)\end{array}$ & $\begin{array}{c}\text { Harvest index } \\
(\%)\end{array}$ \\
\hline BRRI dhan56 & 3.81 & 7.93 & 52.31 \\
BRRI dhan57 & 4.17 & 7.61 & 45.63 \\
Binadhan-7 & 5.26 & 9.86 & 46.96 \\
BU dhan1 & 5.79 & 10.94 & 47.28 \\
BU-9958-40-5-1 & 5.58 & 11.55 & 51.80 \\
\hline CV (\%) & 16.99 & 11.56 & 6.86 \\
LSD $(0.05)$ & 1.58 & 2.09 & 6.30 \\
\hline
\end{tabular}

\section{Conclusion}

Results of the present study indicated that there was variability in performance of short duration Aman rice genotypes. Among the rice genotypes, BRRI dhan57 was earlier (81 DAT) while the advanced line BU-9958-40-5-1 took the maximum days (90 DAT) to mature. However, the advanced line produced the highest grain yield $\left(5.98 \mathrm{t} \mathrm{ha}^{-1}\right)$ coupled with the highest biological yield $(11.55 \mathrm{t}$

ha $^{-1}$ ) but failed to show the highest harvest index. Thus it seemed that this line was not much efficient in converting total dry matter into grain which is the ultimate target of crop production. Therefore, this result can help physiologists and breeders to determine physiological and morphological features of the advanced line BU-9958-40-5-1 that contribute most to increasing dry matter partition into grain.

\section{References}

Alam, M. Z., M. Ahmed, M. S. Alam, M. E. Haque and M. S. Hossain. 2002. Performance of seedling age and seedling raising technique on yield and yield components of transplanted Aman rice. Pakistan J. Biol. Sci. 5: 1214-1216.

Barvestani, Z. T. and H. Pirdashty. 2001. Dry matter and nitrogen remobilization of rice genotypes under different transplanting dates. Proc. $10^{\text {th }}$ Australian Agron. Conf.

BBS (Bangladesh Bureau of Statistics). 2013. The Statistical Yearbook of Bangladesh. Ministry of Planning. Govt.People's Republic of Bangladesh.

Biswas, J. K., M. A. Hossain, B. C. Sarker, M. Hansan and M. Z. Haque. 1998. Yield performance of several rice varieties seeded directly as late Amancrops. Bangladesh J. Life Sci. 10: 4772. 
Growth and Productivity of Short Duration Genotypic

Chowdhury, S. A., M. A. Majib, K. S. Haque, M. Islam, and M. M. Rahman. 1995. Effect of variety on yield and nutritive value of rice straw. Asian. J. Animal Sci. 8: 326-335.

Gomez, K. A. and A. A. Gomez. 1984. Statistical procedures for agricultural research. John Willey and Sons. New York, Chichester, Brisbane, Toronto. pp. 97-129.

Guowei, W., T. Loyold, Wilson and M. M. Anna. 1998. Contribution of rice tillers to dry matter accumulation and yield. Agron. J. 90: 317-323.

Haque, M. M. and M. M. Rashid. 2016. Development of alternative cropping pattern with four crops in sequence in northern Bangladesh. Paper presented in seminar on transforming agriculture for sustainable development. International agricultural conference, organized by KIB, 29-30 Sep., 2016, Dhaka, Bangladesh.

Islam, M. R., M. S. Rahman, M. H. Rahman, M. A. Awal and S. M. G. Hossain.1999. Effect of date of transplanting on yield and yield attributes of two advanced mutants of rice on Amanseason. Bangladesh J. Nuclear. Agric. 15: 34-40.

Kamal, M. M. 2006. Effect of variety and planting method on the growth and yield of Bororice. Thesis M.S. in Agron., Bangladesh Agril. Univ., Mymensingh. pp. 33-35.

Khisha, K. 2002. An evaluating of Madagascar system of rice production in Aman season. M.S. Thesis. Dept. Agronomy. Bangladesh Agril. Univ., Mymensingh. pp. 90-98.

Kumar, R., A. K. Barawagi, C. Ramos, S. T. Amarante, A. M. Ismail and I. J. Wade. 2006. Partitioning of dry matter during drought stress in rainfed low land rice. Field Crops Res. 9:1-11.

Lamberts, L., E. Bie., G. E. Vandeputte, W. S. Veraverbeke, V. Derycke and J. A. Delcour. 2007. Effect of different varieties on growth and development of transplant Aman rice. Manilla J. Agric. Sci. 100(4): 1496-1.

Miah, M. N. H., T. Yoshida and Y. Yomamoto. 1997. Effect of nitrogen application during ripening period on photosynthesis and dry matter production and its impact on yield and yield components of semi dwarf indica rice varieties under water culture conditions. Soil Sci. Plant Nut. 43: 205-217.

Miller, B. C., J. E. Hill and S. R. Roberts. 1991. Plant population effects on growth and yield in water needed rice. Agron. J. 83:291-297.

Mumin, M. A. 2002. Performance of some Amanrice varieties as influenced by planting time. M.S. Thesis, Dept. Agron, Bangladesh Agril. Univ., Mymemsingh. pp. 43-44.

Naha, R. N. 2007. Effect of variety and seedling age on the performance of Aman rice.Thesis, M.S. in Agron., Bangladesh Agril. Univ., Mymemsingh. pp. 34-54.

Ntanos, D. A. and S. D. Koutroubus. 2002. Dry matter and N accumulation for India and japonica rice under Mediterranean conditions. Field Crops Res. 74:93-101.

Reddy, K. G. 2004.Varietal performance special requirement of rice under system of rice intensification during Kharif season. M. Sc. (Ag.) Thesis, Acharya N.G. Ranga Agric. Univ., Hyderabad, India.

Reddy, Y., T. G. Prashad and M. Udayakumar. 1995. Relation between leaf area index, specific leaf weight and assimilation rate in rice genotype. Madras Agril. J. 616-617. 
Hasan et al.

Shamsuddin, A. M., M. A. Islam and A. Hossain. 1988. Comparative study on the yield and agronomic characters of nine Amancultivars of rice in rainfed condition. Bangladesh $\mathrm{J}$. Agril.Sci. 15: 121- 124.

Singh, S. and B. Gangwar. 1989. Comparative studies on production potentials in traditional tall and improved rice cultivars. J. Andaman Sci. Assoc. 5: 81-82.

Udayakumar. 2005. Studies on system of rice intensification (SRI) for seed yield and seed quality. M. Sc. (Ag) Thesis, Acharya N.G. Ranga Agric. Univ., Hyderabad, India.

Yang, J., J. Z. Wang, L. Liu and Q. Zhu. 2003. Post anthesis water deficits enhance grain filling in two-line hybrid rice. Crop Sci. 43: 2099-2108. 